\title{
Debate: Prevention and Victim Compensation
}

\author{
Nisha Varia
}

Afroza, a Bangladeshi woman who worked for sixteen years without getting paid and was not allowed to go home to visit her family. Keni, an Indonesian woman whose employers injured her with a hot iron, leaving disfiguring third-degree burns all over her body. Kartika, an older Sri Lankan woman whose employers made her work around the clock without pay, shaved her head to humiliate her and gouged pieces of flesh out of her arm with knives.

These are some of the women whose faces and stories still haunt me after ten years of investigating human rights abuses against migrant domestic workers in Asia and the Middle East.

When the Anti-Trafficking Review posed the question of how I would spend ten million dollars to fight trafficking, I tried to think about what could have helped these particular women and the hundreds of other domestic workers I have met, who were abused, exploited and, in some cases, trafficked. If I had ten million dollars to fight trafficking, I would spend it on victim-centered measures: prevention and compensation.

Forced labour and human trafficking are complex and entrenched, and there is no one magic programme that, if funded, would fix the problems. Instead, a holistic approach is needed to address many facets of prevention and response.

Arresting, prosecuting and punishing abusive employers, recruiters and others involved in trafficking is a critical part of accountability, deterrence and justice. However, too many governments, international agencies, donors, and civil society groups have pursued a criminal justice response to forced labour and trafficking, while neglecting prevention as well as protection, compensation and survivor rehabilitation.

Afroza, Keni and Kartika all received some assistance from state authorities, but it was well after they had already endured long periods of confinement or savage abuse that had changed their lives forever. Like many of the other empty-handed and traumatised survivors I have met in shelters, airports and deportation centres, their top priorities were to be reunited with their families, to receive their long-overdue wages, and to much-needed healthcare. When I asked Kartika what recommendations she would make to the government, she said she did not want any other Sri Lankan woman to go through what she had experienced.

One way to prevent trafficking is to look at where this exploitation flourishes. It is no mystery. Exploitation often happens in sectors that are poorly regulated and inadequately monitored-for example, domestic work, fishing and agriculture. When governments exclude these workers from standard labour protections such as a minimum wage, safe working conditions, a weekly day off or limits on working hours, they are giving tacit permission to employers to exact excessive work in hazardous

This is an open-access article distributed under the terms of the Creative Commons Attribution License (CC-BY). Under the CC-BY license, the public is free to share, adapt, and make commercial use of the work. Users must always give proper attribution to the author(s) and the Anti-Trafficking Review. 
conditions for a pittance. They are letting employers know that there will be no labour inspectors checking on them, and no clear authority for workers to turn to for help.

Similarly, when governments do not require businesses to conduct due diligence to prevent, monitor and respond to abuse in their operations or supply chains, they are sending a signal to these businesses that anything goes.

When governments prohibit the right to form or join unions, they are limiting workers' ability to exchange information with each other, and to build collective power to balance out a lopsided power dynamic with employers in order to negotiate for safer and fairer working conditions.

And when governments create programmes for temporary migration in which visa conditions tie workers to individual employers, they exacerbate this power imbalance instead of addressing it. Employers wield inordinate control over a worker's fate, and temporary migrants are much less likely to access information about their rights or know where to turn to for assistance in cases of abuse. Other immigration practices, such as disproportionately harsh penalties for immigration offences and routine immigration detention, contribute to leaving victims of forced labour, including labour trafficking, afraid to seek help from authorities.

A frequent misconception is that trafficking takes place mostly through organised crime, hidden in the shadows. Some trafficking fits that description, but other types take place in the context of more widespread, and often normalised, labour rights abuses. Legal gaps and restrictions in many countries-for example, labour laws that exclude domestic workers or deportation policies that deter migrants from reporting workplace abuse-fuel this exploitation, instead of stopping it.

The risk of focusing on legal reform is that it is slow, and can easily get mired in politics, bureaucracy and apathy. Having good laws in place only makes a difference when there is adequate political will, training and capacity for rigorous enforcement.

I would spend part of the money supporting workers' rights groups to keep relentless pressure on governments to enact these changes. For example, I would allot funds to strengthen nascent groups in the Gulf to reach out to migrant domestic workers with information and services, and to amplify their voices in the media and with hostcountry governments. I would promote partnerships between trade unions, advocacy groups and community organisations in labour-sending countries to strengthen their political voice and ability to pressure their governments to adopt and implement reforms.

These groups should be able to provide a constructive and more realistic alternative to the well-meaning but often counter-productive campaigns that dehumanise survivors of abuse as 'modern-day slaves' and obscure the politics around workers' rights, safe migration and gender discrimination.

But until the day when we have won the battle against trafficking, I would ensure that the rest of the money reaches the hands of survivors like Afroza, Keni and Kartika directly, through supporting victim compensation funds that are easily and quickly accessed. 
Nothing can take away the grievous harm they have suffered. Instead of making them jump through hoops for temporary and limited government assistance, or leaving them empty-handed while focusing on lengthy criminal proceedings, getting these funds to victims could give them the time and resources they need to heal and rebuild their lives.

Nisha Varia is a senior women's rights researcher at Human Rights Watch.

Please cite this article as: $N$ Varia, 'Prevention and Victim Compensation', AntiTrafficking Review, issue 3, 2014, pp. 167-170, www.antitraffickingreview.org 